\title{
Domestic Savings in Unit Trusts and the Growth of Capital Market in Kenya
}

\author{
Robert Kipkorir Cheruiyot* $\quad$ Dr. Florence S Memba Dr. Tabitha M Nasieku \\ School of Human Resource Development, Jomo Kenyatta University of Agriculture and Technology, \\ P.O BOX 00200-62000, Nairobi, Kenya
}

\begin{abstract}
Unit trust funds have contributed to the growth of capital market in Kenya and indeed globally. However there is need to determine the specific contribution of unit trust in the growth of capital market; more so, the particular attribute of unit trust that attract the investment. Theoretically it is expected that as unit trust funds grow, capital markets equally grows but empirically there is some substantial growth in capital market though not in equal measure in unit trusts. The study therefore sought to determine the contribution of domestic savings in unit trusts on the growth of capital market. This was undertaken using explanatory non-experimental research design and analysis were carried out using panel data. A census involving all twenty three (23) unit trust schemes for the period 2009 to 2017 was carried out utilizing secondary data. The variables were analyzed using panel data to determine the relationships of the variables by use of fixed effect model. The study revealed a positive effect of domestic savings to the growth of capital market in Kenya. The findings were presented using a linear type of regression model. The study therefore recommend that greater emphasis be placed on domestic saving in order to benefit from its contribution to the growth of capital market and consequently supporting the economic pillar in Kenya vision 2030.
\end{abstract}

Keywords: capital market, domestic savings, growth and unit trusts.

DOI: $10.7176 / \mathrm{EJBM} / 11-16-04$

Publication date:June $30^{\text {th }} 2019$

\subsection{Introduction}

The Kenyan capital market has witnessed a considerable amount of growth, and has assumed an increasingly significant role within the overall financial sector. Much has been done to enhance market infrastructure and processes, and to strengthen the regulatory framework under reference, with the Capital Market Authority (CMA) itself supporting and providing a favorable environment for investment. The capital market has seen significant growth, with a steady increase in the amount of funds raised (CMA, 2011).

Unit Trust Fund is a collective investment scheme designed in such a way that it pools money from numerous investors, with similar financial objectives and delegates the management of these funds to a group of professional managers who undertake to invest the pooled funds in a portfolio of carefully selected securities. The fund managers in return for the money received issues units to investors who are then known as unit holders. The fund earns income from the investment which is then distributed in the form of dividends, capital gains and interest income (Maina, 2013).

The investment in unit trust funds is created to support the development of appropriate capital market structures and mechanisms to support the economic, financial and commercial goals of the country as stipulated in Vision 2030. According to this plan, Kenya will streamline informal finance and savings and credit cooperative organizations as a way of improving savings for investment and make it the regional financial services hub.

According to CMA (2011) the capital market has played a vital role in mobilizing resources and facilitating economic development in the past, the development financing requirements of the economy indicate that even greater demands will be placed on the capital market in the future in order to achieve the national aspirations.

In the U.S, the unit trust industry by year-end 2015 was the largest in the world with an equivalent of $\$ 19.8$ trillion in assets. The growth in the industry has been steady for the past two decades accounting for half of the $\$ 35.4$ trillion in unit trust assets worldwide. Such growth in high income countries has stimulated a large and ever growing literature on unit trusts that can best be used to explain the performances of the industry.

Smith (1997) argued from the study of financial markets in USA that markets enhance growth to the extent that they serve to allocate resources to the place in the economic system where their social return is greatest. Market structures also affect agents' incentives to accumulate various types of physical and human capital, as well as other kinds of assets. Finally, market formation is an endogenous process.

Abdullah, Hassan, and Mohamad, (2007) found out that in Malaysia individual investors seeking liquidity, portfolio diversification and investment expertise are increasingly choosing unit trust funds as their investment vehicle. However, these investors do differ in their preferences based on their risk threshold, liquidity needs and their needs to comply with religious requirement.

South Africa's first unit trust, Sage Fund, was established in June 1965 with approximately R600 000 under management, R41 million at December 2012 price levels. Since then there has been huge growth in the unit trust 
industry in South Africa: from the records by 2012, there were 704 South African domestic unit trust funds available, with a market value of R1 160 billion. Equities dominate South African unit trusts, but the relative popularity of general equity funds has been on a decline since the 1970s (Dino and Mark, 2015).

Based on the assessment of the sources its financial resources and enabling environment there is sufficient evidence that the fundamentals exist for the continent to raise more financial resources domestically to implement its development programmes and projects. In addition to the fundamentals, Africa's resource potential is enormous and strongly confirms that the continent has the means to finance its own development (NEPAD, 2013).

Further, NEPAD (2013) argues that one of the features of Kenya's capital and financial services is its degree of diversification of fairly well established institutions and instruments of mobilization of domestic resources. Kenya's capital and finance market today boasts of one of the oldest and fairly well established stock exchange markets in Africa; a banking sector with about 43 commercial banks with their 1,143 branch network, including a variety of non-bank financial institutions; an insurance industry, ranked 4th in Africa and 71st globally in 2006 in the last few years; a well-established capital market managed under the Capital Markets Authority.

Private savings have increased over the years driven by rising per capita income, higher age dependency ratio, lower share of agriculture in the economy and continued efforts to deepen the financial system. It is anticipated that private savings will have to provide the bulk of the additional investment-financing requirement, especially through the increasing role of the capital market (Mohamed and Chze, 2001).

In Kenya, Unit trusts are regulated by CMA, a corporate body set up in 1989 through an Act of Parliament with the mandate of promoting, regulating, and facilitating the development of orderly, fair and efficient capital markets. According to CMA, unit trusts are increasingly becoming the small investor's solution in finding a wide range of investment diversification without the need of prohibitive funding (Shikuku, 2012).

The government has put in place measures to enhance the capacity of the Capital Market Authority (CMA) and the Nairobi Securities Exchange (NSE) to enable the two institutions to play their respective roles. In order to encourage more stock exchange listings the government has eliminated existing obstacles and encouraged collective savings institutions (mainly collective investment schemes, insurance companies and pension funds) this will increase the potential to increase funds for investments (ROK, 2007).

The type of products chosen by investors to place their capital depends mainly on their monetary goals, time frame, and total capital accessible. Unit trusts have grown in recognition and popularity in recent years. This can be proven by the growth in the numbers of approved unit trust funds from virtually zero in 2001 to 23 by 2016 . As a market environment becomes more sophisticated and volatile, unit trusts become safe havens for less sophisticated and less capitalized, including also the conservative individuals in the market place (CMA, 2011).

Although CMA provides laws and guidelines that aid investor protection, it is ultimately investor's duty to evaluate the suitability, profitability and viability of any investment. An investor must comprehend the information which is required to be provided in the prospectus and make the choice whether to invest or not, based on their own situation and attitude to risk (CMA, 2007).

There has been a progressive growth in unit trust but at a slower rate than expected. However, like other businesses which swim through the waves of business challenges to remain in the right momentum, some collective investment schemes in Nairobi appear to have several challenges ranging from stiff competitors who make some to die before they are even launched or go through a very short life span compared to other businesses (Zimele, 2010).

Kenya faces a marked slowdown in credit growth to the private sector. At $4.3 \%$, the credit growth rate remains well below the ten-year average of $19 \%$ and is weighing on private investment and household consumption. Also, as a net oil importer, the rise in global oil prices compared to the lower prices in 2016 has significantly slowed the economic activity. This has a negative net effect on investment in available investment options including unit trust (CMA, 2017).

According to CMA (2017), the total collective investment schemes funds under management as at Dec 31 , 2016 stood at KShs 57 billion. Out of this CIC Unit Trust Scheme manages 23\% of the total funds. It is also noted that $78 \%$ of this funds are invested in the money markets.

In this context, it becomes pertinent to study the contribution of domestic savings in unit trust to the growth of the Capital Market in Kenya. The vision 2030 developed by the Kenya Government anticipated that financial services are made vibrant and globally competitive financial sector to drive high-levels of savings to finance Kenya's investment needs. The objective will be achieved by raising institutional capital through policy frameworks that are favorable locally in tapping available sources of capital.

\subsection{Statement of the Problem}

There is a shift from traditional forms of savings, particularly bank deposits, towards managed mutual funds resulting in a change in the focus in the structure and nature of financial services from institutions to individual investor (Rudman, 2008). This drastic growth and the shift in risk bearing have raised concern about the level of investor's knowledge or lack thereof relating to the cost, risk and other factors associated with investment decisions. 
In addition, the Capital Market Authority through its policy incentives of 2005/2006 approved that all Income accruing to registered CISs as tax free in order to encourage pooling of resources from small investors so as to boost the demand for securities in the capital markets. Consequently, investors are able to consider a variety of factors when making investment selections in the capital market where unit trusts is one of the options. This leads to the question 'what is the contribution of domestic savings in unit trust on the growth of capital markets in Kenya?'

In Kenya, as at 2016, there were 23 registered unit trust funds from virtually none in 2001 compared to 526 funds currently operating in South Africa. This implies that there is huge potential to tap in terms of capital formation in the capital market. In line with Vision 2030, investment in unit trust funds will support the development of appropriate capital market structures and mechanisms to support the economic, financial and commercial goals of the country. To achieve this objective under Vision 2030, there is need to create a vibrant and globally competitive financial sector that will promote high levels of savings to finance Kenya's overall investment needs.

The theory of investment value points out that an investment operation is one which, upon thorough analysis promises safety of principle and an adequate return; operations not meeting these requirements are speculative. Graham (1974) further argues that the market is a pendulum that forever swings between unsustainable optimism and unjustified pessimism however the intelligent investor is a realist.

Kagunda (2015) asserts that the unit trusts are attractive mainly because of the minimum risk involved as well as professional management. In addition, unit trusts have performed well and the market trail behind the performance of unit trusts. The fact that the unit trust outperforms the market can be attributed to the fact that fund managers could be in the position to predict stock prices based on several fundamental variables such as initial dividend yield, market capitalization, price earnings ratio and price to book value ratios.

Investment decisions in unit trusts are influenced by behavioral biases of individual fund managers. Anchor and overconfidence are found to be the most dominant factors affecting fund managers investment decisions. Fund managers choose to retain the best performing portfolios in their current investment in anticipation of continuous better returns suggesting the effect of anchor in their decisions (Shikuku, 2012).

Investment choices available to investors need to undergo a thorough analysis of the situations prevailing in an economy. Unit trust funds are key pillars in the capital market needed to mobilize financial resources to the capital market as identified in Kenya vision 2030. To achieve this, unit trust funds should promises safety of principle and an adequate return as well as making substantial contribution to the growth of capital market in Kenya.

It is true that when unit trust funds grow we expect also a growth of capital markets, but this is not necessarily true in all situations. There has been a progressive growth in Unit Trust but at a slower rate than expected with few firm taking the lion share of the funds. Therefore there is need to determine the specific mix in the unit trust which act as a magnet to draw investors consequently the growth of capital market in Kenya. This is important because comparing unit trust industry with other countries, there are fewer unit trusts are registered with CMA and further listed with NSE. It is against this background that this study seeks to fill the gap by bringing out the contribution domestic savings in unit trust funds on the growth of capital markets in Kenya.

\subsection{Specific Objectives}

To determine the contribution of domestic savings on growth of capital market

\subsection{Research Hypothesis}

$\mathrm{H}_{\mathrm{O}}$ : There is no significant relationship between domestic savings and the growth of capital market

\section{LITERATURE REVIEW}

\subsection{Introduction}

This section presents both theoretical and empirical literature reviews in the order of fundamental aspects that define the study variables. Section 2.2 presents the theoretical literature, section 2.3 provides the conceptual framework and Section 2.4 discusses the empirical literature.

\subsection{Theoretical Review}

This section gives a review of two theories related to investment in unit trusts. The theories reviewed are the theory of investment value and Institutional herding theory. The endogenous growth model is also reviewed in this chapter.

\subsubsection{The Theory of Investment Value}

The seminal work of John Burr Williams which was later published in 1938 introduced the Theory of Investment Value. Williams was a security analyst who sought a better understanding of what caused the stock market crash of 1929 and the subsequent great depression. The study focused on the intrinsic value of common stock which was published as the theory of investment value. 
According to Williams, investment value is the present worth of future dividends, or of future coupons and the principal. In this regard, it is of practical importance to every investor because it is the critical value above which he cannot go in buying or holding, without added risk.

The Theory of Investment Value shows how traders would act in the stock market if they were perfectly rational and farseeing. It is noted that gradually as men do become more intelligent and better informed, market prices should draw closer to the values given by this theory since market prices depends on popular opinion, and since the public is more emotional than logical. It is foolish to expect a relentless convergence of market price towards investment value.

According to Graham (1974) review on the theory of investment value, common stocks have certain important characteristics including the speculative characteristic. Their investment value and average market price have a tendency to increase erratically but steadily over time, as their total value builds up through the reinvestment of undistributed earnings taking into consideration the effect of inflation. However, to calculate the investment value it requires consideration of factors not limited to future growth of earnings, the proportion of earnings payable as dividends, and an estimated discounting rate applicable.

The Theory of Investment Value focuses on the investment made and the expectations of the investor on the behavior of this investment over a period of time. This therefore forms a foundation to support the objective of this study.

\subsubsection{Herding Theory}

The Herding Theory, is credited to Scharfstein and Stein (1990), arising from classic paper by Grossman and Stiglitz (1976). The theory explains the general behavior involved in decision making where investors mimic each other and trade following the pattern of those considered more knowledgeable rather that investment based on their beliefs or private information.

The theory further paints an investor as a communicator, who issues and receives informative signals and then convey the same information between individuals in different shapes (Maloba, 2012). Institutional herding is a kind of a trading model where institutional investors buy and sell the same set of securities at the specified period. Herding behavior has been frequently regarded as a key feature of institutional trading. According to the model, institutions investors are subjected to reputational risk when they act in a different way from the masses. A justification for reputational herding is that investors consider failing conventionally better for one's reputation than succeeding unconventionally. This is because investors who herd comfortably share the blame and hide in the herd when making unfavorable investment decisions. (Cai, Han, and Li, 2012).

The existing theories explaining why institutional investors might herd indicate that institutions may trade jointly purely because they receive interconnected private information, perhaps from interpreting the similar indicators or share certain preferences for some securities with particular characteristics, such as liquidity, volatility or visibility of the stocks. Institutional investors may also consider private information from the historical trades of knowledgeable institutions and trade in the same pattern, in doing so; they may pay no attention to their private information and trade with the crowd due to the reputational risk of behaving differently from other fund managers (Cai et al., 2012).

Chiang and Zheng (2010) noted that herd behavior in financial markets is a relevant subject of discussion for both practitioners and economists. Economists are particularly interested in herding due to the behavioral effect on stock prices which affect returns and risk characteristics consequently asset pricing models. Practitioners also interested in herding among investors since it creates profitable trading opportunities hence increasing the value of investment on behave of investors.

This theory forms the basis for this study as it explains herd behavior among fund managers and investors which effect the financial decision making process resulting in price reactions of securities. This in addition brings out the favorable movement of price of assets toward its intrinsic value and consequently stability of the market.

\subsubsection{The Endogenous Growth Model}

The Endogenous Growth Theory is linked with Rivera-Batiz and Romer (1991) and Grossman (1992). Endogenous growth theory explains long-run growth as emanating from economic activities that generate new technological knowledge resulting from the rate of investment, the volume of the capital stock, and the extra investment in human capital.

The technical progress of endogenous model makes the long-run growth stable and permanent. The profitmaximizing behavior of firms is driven by Innovation, imitation and adaptation as a way to achieve the objective. In so far as externalities might be associated with these activities, the costs of innovation, imitation and adaption are covered by short-term profits that allow to firms to set prices accordingly (Young, 1993).

Endogenous Growth Theory further describe growth in economies which is generated by factors within the production process, such as; economies of scale, increasing returns and induced technological change; contrary to external factors including the increases in population. In all this process Capital accumulation finally becomes a profitable long-run business (Brown and Nyeche, 2016)

In a broader sense positive externalities are directly linked to capital accumulations which lead to constant or 
even increasing returns of the accumulable factor (Romer, 1987). Positive externalities shelve the assumption of diminishing returns on capital as stated in the neoclassical model and instead focus on permanent increases in the growth rate. These positive externalities include physical investment, knowledge and human capital accumulation. (Romer, 1986).

This theory of economic growth as discussed explains the component of growth of capital market which is as a result of variables stated in the objective of this study. The growth theory emphasizes that economic growth results from increasing returns to the use of knowledge though its limited applicability lies in its assumptions. The theory argues that knowledge is different from other economic goods because of its possibility to grow boundlessly. It is important to note that capital accumulation directly determines future growth. Policy intervention is thus considered necessary to influence growth in the long term. The growth model, therefore, promote the role of government and public policies in complementary investments in human capital formation and the encouragement both foreign and private investments in the capital market.

\subsection{The Conceptual Framework}

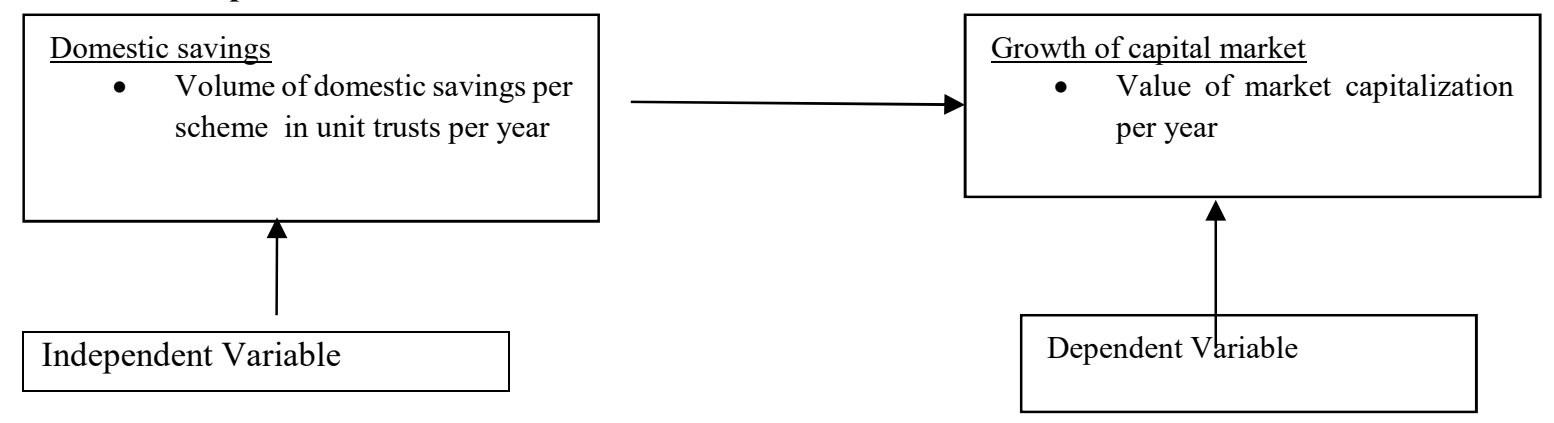

\subsection{Empirical Review}

\subsubsection{Domestic savings}

Wamburu and Wainaina (2014) studied the determinants of Stock Market Development using error correction model to appraise what determines stock market development in Kenya. The objectives of the study were to evaluate the effect of institutional factors on the stock market development, to investigate the effect of macroeconomic factors on the stock market development and to investigate the social political and economic stability on the development of stock. Using descriptive approach they provided evidence capital markets can significantly raise the level of domestic savings and contribute to a more efficient allocation of such savings among competing uses.

Allahawiah and Al Amro (2012) investigated the factors affecting stock market prices in Amman Stock Exchange. The study focused on firm-specific variables such as dividend policy, management quality, financial position, firm size, and nature of business collected from both primary and secondary sources. All the variables had positive and significant effects on stock market prices. This study therefore revealed that firm-specific factors are important determinants of stock market development.

The Ministry of Finance and Economic Planning [MINECOFIN] (2013) by the Government of Rwanda in its publication on National Savings Mobilization Strategy gave an outline indicating that voluntary saving depends on the power to save and the readiness to save. The power to save depends on three main factors: the level of per capita income; the growth of income, and the distribution of income. The willingness to save depends, in turn, on: the rate of interest; the existence of financial institutions; the range and availability of financial assets, and the rate of inflation. The report further identifies six pillars as the basis of Rwanda national savings mobilization strategy and creates a culture of savings. These are: macroeconomic stability, institutionalized savings, expansion of the financial infrastructure and intermediation, safe and diversified way of savings, building capability and effectiveness of intermediation, and better awareness of tangible advantage of savings.

Aduda, Masila and Onsongo (2012) sought to examine the determinants of development in the Nairobi Stock Exchange. The study employed regression analysis to analyze data obtained from secondary sources for the period 2005 - 2009 to determine the factors influencing the development of the NSE. It was noted that domestic savings affects positively the stock market development at $1 \%$ level, which is in line with theory as reflecting financial intermediation role of stock market. An increase in domestic savings by one Kenya shillings leads stock market expansion by Kenya shillings 4.209 , Indicating that savings are directly related to investment. This has a direct link to the level of investment in the economy as the investors add more investment in stock market and increase their production to meet the increased demand. As the economy grows and investment increases, people invest from their earlier savings

The study by Onuora, Edith, and Onyeanu (2013) focused on Examining the Unit Trust Scheme as a Veritable Vehicle of Investment in the Nigerian Stock Market. The author noted that in spite of the numerous benefits of 
Trust Fund and its very vital prospect as a veritable instrument for pooling of capital for meaningful investment in Nigeria not many investors within are either aware of this vehicle nor appreciate its prospects. The Nigerian economy needs much domestic investment to be able to grow at a desired double digit rate, so as to grow and enable the country achieve the Millennium Development Goals (MDGs). Notwithstanding low per capita income, the unit trust becomes the only viable vehicle for mobilizing small scale savings to be able to invest meaningfully in the real sector.

\subsubsection{Growth of capital market}

Nzoka (2013) did a study on the factors influencing growth strategies of fund management firms in Kenya. The study used primary data which was analyzed using descriptive statistics involving mean scores and was used to show the average effect of the factors under investigation. The author argues that incentives for growth include the need for survival. A firm that does not attempt to grow will not merely standstill but also stagnate and eventually die. On the other hand well planned expansion is not stimulating but also present to the executive a challenge similar to the one of difficult climbs in mountaineering. In addition to the managerial stimulus, growth confers tangible financial benefits to the firm. In the short run the output of the firm is prone to rise as rate of output increases. As the size of the firm increases, it's likely to reap economies of scale at both production and managerial level.

Nzoka (2013) further argued that, apart from fitting the organization into the changing business environment, organizations pursue growth in order to stretch and exploit the existing competencies and resources as well as meet the expectations created by regulatory and governance frameworks as well as powerful stakeholders. Growth may also be driven by the need to respond to the environment by fitting the business into the environment. Business growth however is not without challenges and constraints.

In a study on the performance of Malaysian unit trusts investing in domestic versus international markets, Abdullah and Abdullah (2009) utilized The Kuala Lumpur Composite Index (KLCI) as the local funds' benchmark. The Morgan Stanley Capital international All Country (MSCI AC), Asia Pacific and MSCI World Free as the international funds' benchmarks. The author concludes that the risk-adjusted performance of internationally diversified funds is not significantly different from the performance of well-diversified domestic funds. There are limitations that need to be considered in applying the findings of this study. The risk-adjusted returns of the local and international funds were calculated without taking into consideration the costs included in investing in the funds, the risks to be borne and the diversification benefits of each type of fund.

\subsection{3: Relationship between domestic savings in unit trust and the growth of Capital Market}

UNODC (2011) developed a research report on estimating illicit financial flows (IFF) resulting from drug trafficking and other transnational organized crimes. The report concludes that there are various channels through which IFF negatively affects domestic resource mobilization and, ultimately, economic growth and opportunities for structural transformation. The possible sources include distortions in the resource distribution from highyielding investments options to investments with low risk detection; distortions of prices, particularly in the real estate sector; distortions of consumption and effect on imports; distortion of exports and potential troubles with investment and economic growth; inequitable competition; risks of crowding out licit activities and depressing impact on foreign direct investment; corruption; risks of real sector instability; strengthening of distorted income and wealth distribution; distortion of economic statistics and thus potential errors in economic policy decision making; and undermining the credibility of legal institutions.

Sejjaka (2013) study on the challenges to the growth of capital markets in underdeveloped economies: the case for Uganda made significant findings. Data across the years 2003 - 2007 was used regarding the study variables and to test the hypothetical model. The conclusion suggests that policy change can result in significant improvements in market development. An increase in incentives to direct local savings away from real assets to financial assets would result in availing more funds for investment. An increase in liquidity by developing secondary market capacity would also further increase the synergies for growth. There is thus a need for a concerted effort to grow capital markets by reshaping attitudes to share capital formation and share ownership.

Gordon (2008) found out that financial services stimulate savings, investment and growth of GDP and to be precise economic growth by escalating the rate of capital buildup and by also improving the effectiveness with which the economies use that capital. Regression analysis and savings-investment models were found to be useful to analyze how the financial sector impacts on investment, savings and growth of the whole economy.

\section{0: Research Methodology}

A research philosophy is a belief about the way in which data phenomenon should be gathered, analyzed and used. The choice of a research philosophy determines the research design. Coopers and Schindler (2004) stated that in social sciences, there are two main research philosophies, that is; the positivism (scientific) and phenomenology (interpretivism).

The positivist approach involves scientific principles, causal relationships, highly structured methodology, large samples, quantification and incremental contribution to theory. Adeoluwa, (2016) asserts that the positivist 
position is characterized by the testing of propositions developed from existing theory, with empirical verification sought through measurement of observable social realities. Phenomenology paradigm (Interpretivism) on the other hand, follows the qualitative tools of observation, questioning, and description. It is associated with qualitative approaches to data gathering.

This study is anchored on the positivist research paradigm which is an approach that seeks facts or causes of social or business phenomena, with little regard to the subjective state of the individual. Considering the rationale of this study, the type of investigation, the extent of researcher involvement, the time period over which data was be collected and the type of analysis, the philosophical foundation guiding this study was positivism. Under this the existing theories has been used to develop hypotheses.

This study adopted an explanatory non-experimental research design to analyze the performance of unit trust firms listed in the NSE, Kenya. According to Kerlinger (1973) an explanatory non-experimental research design is appropriate where the researcher is attempting to explain how the phenomenon operates by identifying the underlying factors that produce change in it in which case there is no manipulation of the independent variable.

The target population for this study was 23 unit trust firms listed at the NSE as at 31st December 2016. The study consequently adopted a census approach because of the small number of unit trusts companies in the NSE. According to (Saunders, Lewis and Thornhill 2007) a census approach enhances validity of the collected data by including certain information-rich cases for study.

The study utilized mainly secondary data sources. The required data was gathered through relevant annual financial publications, surveys and reports of the unit trusts in Kenya. Data on domestic savings of unit trusts were collected from the respective unit trusts firms for the annual period from year 2009 to year 2017.

The data obtained from the process were analyzed using correlation analysis, and panel multiple regression analysis. To test the hypothesis and determine the contribution of domestic savings, panel data analysis was employed. The SPSS results output on test between -subjects effects on growth of capital market determined whether to accept or reject the null hypothesis. This model proved appropriate and provided accurate interpretation.

\subsection{Model Specification}

The study used panel data to carry out the research analysis for 9 years starting from 2009 to 2017. According to Sporta (2018), panel data approach provides the researcher with a large number of data points, which in turn increases freedom while decreasing the collinearity. This means that efficiency of econometric estimates is easily achieved in the study. Gujarati (2012) further suggested various estimating methods that are used in the estimation of the panel data that is pooled OLS, Random effect and Fixed Effect.

The preference of this estimation method is not only because it enables a cross-sectional time series analysis which usually makes provision for broader set of data points, but also because of its ability to control for heterogeneity and endogeneity issues. Hence panel data estimation allows for the control of individual-specific effects usually unobservable which may be correlated with other explanatory variables included in the specification of the relationship between dependent and explanatory variables (Hausman and Taylor, 1981). The framework for panel data regression for this study took the form:

$\mathrm{Y}_{\mathrm{it}}=\alpha_{\mathrm{i}}+\beta_{1} \mathrm{X}_{\mathrm{it}}+\mathrm{u}_{\mathrm{it}}$

Where $\mathrm{u}_{\mathrm{it}}=$ error term

$Y_{\text {it }}=$ growth of capital market for $i^{\text {th }}$ schemes in $\mathrm{t}^{\text {th }}$ year.

$\mathrm{X}_{\mathrm{it}}=$ representing independent variables for firm $\mathrm{i}$ in year $\mathrm{t}$,

$\beta_{1}=$ Coefficients of the independent variables,

$\alpha_{i}=$ the intercept for each scheme,

$\mathrm{i}=1,2 \ldots 23$ (individual unit trust firms),

$\mathrm{t}=1,2 \ldots 9$ (time indicator).

Fixed effect model and random effect model are important tests to estimate the parameters. In this case fixed effect model has been found useful to investigate the connection between predictor and outcome variable within the entities. This is because each entity has its own specific attributes that may or may not influence the predictor variables. Fixed effect model is used with the assumption that something within the individual may have an impact or bias to the predictor or outcome variables therefore there is need to have a control mechanism for this. This is the justification behind the assumption of the correlation among entity's error term and predictor variables. FE in addition removes the effect of those time-invariant characteristics to allow proper assessment of the net effect of the predictors on the final outcome variable. In every study each entity is unique therefore both the entity's error term and the constant should not be correlated at all. Situations where error terms are correlated, then FE is not an appropriate model since inferences may be misleading and hence the need to model the relationship (Oscar, 2007). The following panel data models capturing the above variables have been estimated in the study:

$\mathrm{Y}_{\mathrm{it}}=\alpha_{\mathrm{i}}+\beta_{1} \mathrm{X}_{\mathrm{it}}+\mathrm{u}_{\mathrm{i}}$

Where $\mathrm{u}_{\mathrm{it}}=$ error term

$\mathrm{Y}_{\mathrm{it}}=$ growth of capital market for $\mathrm{i}^{\text {th }}$ schemes in $\mathrm{t}^{\text {th }}$ year. 
$\mathrm{X}_{\mathrm{it}}=$ representing independent variables for firm $\mathrm{i}$ in year $\mathrm{t}$.

$\alpha_{\mathrm{i}}=$ the intercept.

$\beta_{1}=$ Coefficients of the independent variables.

A random effect allows for time-invariant variables to play a role as explanatory variables because of the assummption that the entity's error term is not correlated with the predictors. A random effect further allows generalizing the inferences from the study beyond the sample used in the model (Oscar, 2007). Random Effect model as used followed the equation below.

$\mathrm{Y}_{\mathrm{it}}=\alpha+\beta \mathrm{X}_{\mathrm{it}}+\mathrm{u}_{\mathrm{it}}+\varepsilon_{\mathrm{it}}$...

Where $u_{i t}=$ between entity error term and $\varepsilon_{i t}=$ within entity error term

\section{0: Research Findings and Discussion}

\subsection{1: Correlation Analysis}

The study used correlation matrix to check for pattern of inter-relationship among the study variables. This was used to bring out the nature of relationship between domestic savings and growth of capital market as shown in Table 4.1 .

\section{Table 4.1: Correlation Analysis}

\begin{tabular}{llc}
\hline & & Domestic Savings \\
\hline \multirow{3}{*}{ Growth of Capital Market } & Pearson Correlation & $.620^{* *}$ \\
& Sig. (2-tailed) & .000 \\
& $\mathrm{~N}$ & 160 \\
\hline
\end{tabular}

**. Correlation is significant at the 0.01 level (2-tailed).

*. Correlation is significant at the 0.05 level (2-tailed).

The summary of analysis on Table 4.1 gives a positive correlation coefficient of 0.6 between domestic savings and the growth of capital market. This concludes that there is statistical significant relationship between the two variables under study.

\subsection{2: The Hausman Test for Model Effects Estimation}

So as to set up which estimation effect (between fixed and random) provided superior test results for the study, Hausman test was carried out for the panel regression models as set out in the analysis. The test was led against the null hypothesis that random effect model was the most appropriate model. The test outcomes dismissed the null if the chi-square results were significant at $5 \%$ level of significance.

First, a fixed-effects model was fitted to capture all temporally constant individual-level effects, and then this was compared with the random effect model.

Table 4.2 Hausman specification test

\begin{tabular}{l|lllc}
\hline \multicolumn{5}{c}{ Coefficients } \\
& (b) fixed & (B) Random & Difference (b-B) & Sqrt (diag (vb-vB)) S.E \\
\hline $\begin{array}{l}\text { Domestic } \\
\text { Savings }\end{array}$ & -0.005643 & -0.005342 & & 0.0032 \\
\hline
\end{tabular}

$\mathrm{b}=$ consistent under Ho and Ha; obtained from xtreg

$\mathrm{B}=$ inconsistent under $\mathrm{Ha}$, efficient under Ho; obtained from xtreg

Test: Ho: difference in coefficients not systematic chi2 (2) $=167.34$

Prob $>$ chi $2=0.0000$

Under the current specification, the initial hypothesis that the individual-level effects are adequately modeled by a random-effects model is categorically rejected. This conclusion is based on the rest of the model specification, and random effects were considered to be appropriate for some alternate model of capital growth in the unit trust capitalization in the market.

\subsection{Regression Analysis}

The analysis followed a panel regression analysis to evaluate the estimates of individual contribution of the independent variables on growth of capital market. The study used a nine year period from 2009 to 2017 where parameter estimates was explored as in Table 4.3. 
Table 4.3: Parameter Estimates: Domestic Saving on Growth of Capital Market

Dependent Variable: Growth of Capital Market

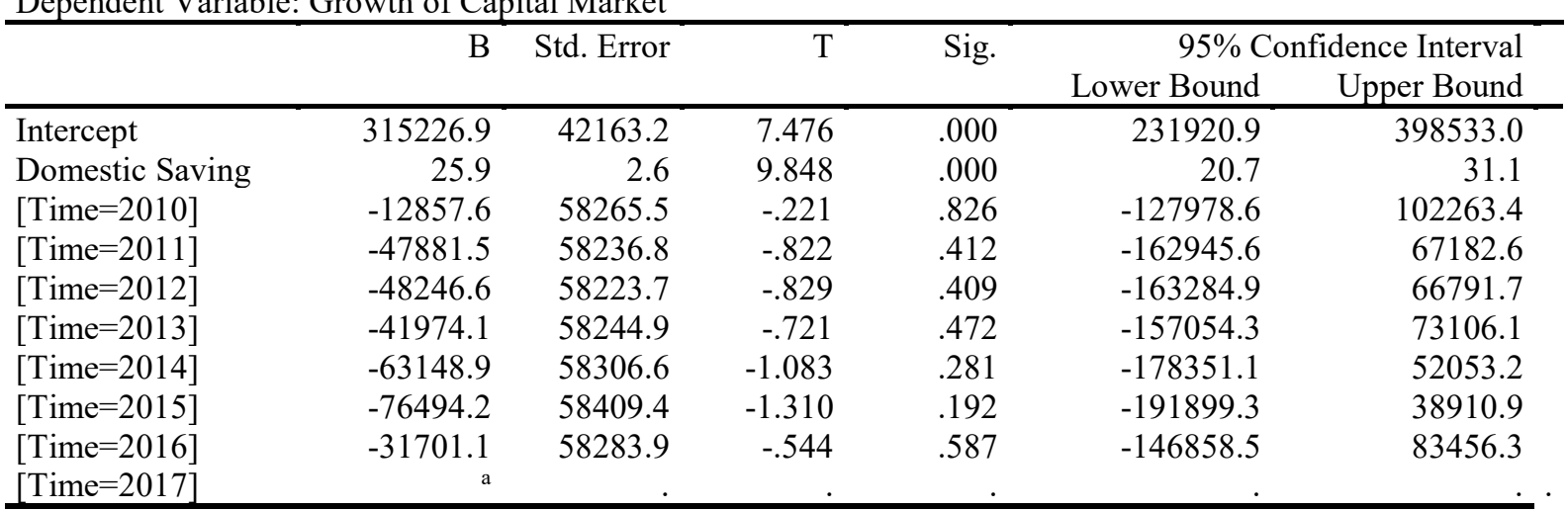

a. This parameter is set to zero because it is redundant.

$\mathrm{y}=\alpha_{1 \mathrm{t}}+\beta_{1 \mathrm{t}} \mathrm{x}_{1 \mathrm{t}}+\varepsilon$

$y=315226.9+25.9 x$.

The parameter estimates in table 4.3 shows contribution of domestic savings, as well as its standard error and confidence interval. The findings of the study reveal that for every one unit increase in domestic saving, there is subsequent increase of growth in capital market of 25.9 units at $95 \%$ C.I $(4.9,8.0), p=0.000$. This is fairly large amount of influence on growth of capital.

The finding agrees with research work conducted by NEPAD (2014) on mobilizing domestic financial resources for implementing NEPAD national and regional programmes and projects. The study concludes that Africa needs to come up with new and innovative mobilization of domestic resource instruments and strengthen the effectiveness and efficiency of existing one, to enable countries sustain long term growth. Onuora and Onyeanu, (2013) further examined unit trust schemes as a Veritable Vehicle of Investment in the Nigerian Stock Market, the study established that the Nigerian market stands to gain substantially from the strengthening of institutional and systemic factors to promote the investment around unit trust schemes which brings about vibrancy in stock market.

This study is supported by similar studies conducted to look into whether investors are able to derive more profits by investing overseas as compared to investing in the domestic market by means of unit trusts. It was found out that the mean returns of the locally managed funds emerge to surpass those of the international funds. Additionally when the returns were risk-adjusted by means of the Sharpe measure, the internationally diversified funds performed in the same way as the domestic funds (Shano, Ganesh and Mwaura, 2014)

\subsection{1: Test of hypothesis}

However, to test the null hypothesis that "there is no statistically significant relationship between domestic savings and growth of capital market" panel data analysis was employed. This was necessary because both variables were measured at multiple time points. A General Linear Model (GLM) was used to look into fixed and random effects on growth of capital using ML (maximum likelihood) estimation. The independent variable was the variables on domestic savings. This was provided through by fund statistics for different products across the years. The dependent variable was the Capital Market capitalization in the same period. The model produced would take the form of; $y=\alpha_{1 t}+\beta_{1 t} x_{1 t}+\varepsilon$. The " $\mathrm{t}$ " element considers the point when the independent variable was recorded. This means that the model was time fixed; this is because some asset statistics did not start on 2009 but delayed. By fixing for the time, the contribution for individual asset funds was ably measured. Table 4.4 shows SPSS results output on test of between -subjects effects on growth of capital market.

Table 4.4: Tests of Between-Subjects Effects: Domestic Saving on Growth of Capital Market Dependent Variable: Growth of Capital Market

\begin{tabular}{lrrrrr}
\hline Source & Type III Sum of Squares & Df & Mean Square & F & Sig. \\
\hline Corrected Model & $3345002524592.1^{\mathrm{a}}$ & 8 & 418125315574.0 & 12.3 & .000 \\
Intercept & 8141490350851.5 & 1 & 8141490350851.5 & 240.2 & .000 \\
Domestic Saving & 3287969072457.8 & 1 & 3287969072457.8 & 96.9 & .000 \\
Time (Years) & 87294755761.8 & 7 & 12470679394.5 & .36 & .920 \\
Error & 5118846295134.3 & 151 & 33899644338.6 & & \\
Total & 30943345492816.0 & 160 & & & \\
Corrected Total & 8463848819726.4 & 159 & & & \\
\hline
\end{tabular}

a. $\quad$ R Squared $=.395$ (Adjusted R Squared $=.363$ )

The findings as shown in table 4.4 shows Type III Tests of Fixed Effects. The results reveals that domestic saving was significant at the 0.05 level $[\mathrm{F}(1,151)=96.9, \mathrm{p}=0.000]$, while the fixed factor (time) was not significant 
$(\mathrm{p}=0.920)$. This means that domestic saving is an important predictor of growth of capital market. Given, that calculated p-value $=0.000$ is less than the prior significant level of 0.05 , the null hypothesis was rejected and conclusion reached that there is statistically significant relationship linking domestic savings and growth of capital market, with improvement in domestic saving resulting into increase in growth capital market and vice versa.

\subsection{2: Evaluating Contribution domestic savings}

The study sought to investigate the level of contribution of domestic savings factored in the model in the prediction of the dependent variable. This was shown by coefficients values in Table 4.5:

Table 4.5: Coefficient Output: Unit Trust Funds on Growth of Capital Market

\begin{tabular}{|c|c|c|c|c|c|}
\hline \multirow[t]{2}{*}{ Model } & \multicolumn{2}{|c|}{ Unstandardized Coefficients } & \multirow{2}{*}{$\begin{array}{c}\begin{array}{c}\text { Standardized } \\
\text { Coefficients }\end{array} \\
\text { Beta }\end{array}$} & \multirow[t]{2}{*}{$\mathrm{t}$} & \multirow[t]{2}{*}{ Sig. } \\
\hline & $\mathrm{B}$ & Std. Error & & & \\
\hline (Constant) & 628223.9 & 113577.3 & & 5.531 & .000 \\
\hline Domestic Savings & 22.2 & 5.361 & .542 & 4.152 & .000 \\
\hline
\end{tabular}

a. Dependent Variable: Growth of Capital Market

From the coefficient output table it is evident that domestic savings in unit trust had a statistically significant influence on growth of capital market in Kenya. The contribution of domestic savings had some positive and substantial impact growth of capital market. The variable had the large beta coefficient of $0.542(\mathrm{p}<.05)$, implying that it made the distinctive contribution to explaining the dependent variable. This means that a one standard deviation improvement in capital allocation leads to a 0.542 standard deviation increase in growth of capital market.

\section{0: Conclusion and Recommendation \\ 5.1 Conclusion}

The study investigated the contribution of domestic savings on growth of capital market. The coefficient value indicating the level of specific contribution of the predicator in the model in predicting the dependent variable established that domestic saving had statistically significant influence on growth of capital market in Kenya. The positive effect of domestic savings on the growth of capital market may be explained by the fact that higher savings may increase the financial influence on capital market activity. In view of these findings, the study concludes that capital markets can put in place mechanism to significantly raise the level of domestic savings and contribute to a more efficient allocation of such savings among competing uses which in turn contribute to the growth of capital market.

\section{2: Recommendations}

A strengthening of the information infrastructure for unit trust should be part of the broader policy strategy needed to develop efficient and liquid capital markets for these financial instruments as well as to enhance open access to a wide range of capital markets products and services. Investor education is critical in improving investor knowledge on the wide range of investment products as well as enhancing investor protection and scrutiny of collective investment schemes.

The relationship between domestic savings on growth of capital market was established to be positive relationship. Hence it is recommended that Managers of collective investment scheme and capital market authority to increase awareness and encourage investment through the expansion programs of mobilizing saving within the country.

The study in addition recommends that more attention be placed on domestic saving due to its ability to help the country enhance its growth, economic performance, contribute towards increasing policy space and reduce aid dependence. It is important to note that as much as the private sector plays the significant role in the process of planning, mobilizing and investing domestic resources, the ultimate policy and institutional drivers are in the hands of the Kenyan government.

\section{3: Suggestion for Further Research}

This study used secondary data for analysis. Given the relevance of capital market in the realization of vision 2030 in Kenya, it may be beneficial for a similar study to be carried using secondary data on the position of unit trust in the realization of Vision 2030 and Capital Market Master Plan 2014-2023. The study can also focus on whether the capital market implementation plan is realizing the goal of achieving a savings rate of $30 \%$ of GDP as stipulated in the Economic pillar of Vision 2030.

\section{REFERENCES}

Allahawiah, S. Amro, S. (2012). Factors affecting Stock Market Prices in Amman Stock Exchange: A Survey Study. European Journal of Business and Management, Vol 4, No.8, www.iiste.org ISSN 2222-1905 (Paper) ISSN 2222-2839 (Online). 
Abdullah, N. A., \& Abdullah, N. A. H. (2009). The performance of Malaysian unit trusts investing in domestic versus international markets. Asian Academy of Management Journal of Accounting and Finance, 5(2), 77100.

Adeoluwa, S. Z. (2016). Relationship between Accounting Information and Equity Share Investment: Evidence from Listed Companies in Nigeria.

Abdullah, F., Hassan, T., \& Mohamad, S. (2007). Investigation of performance of Malaysian Islamic unit trust funds: Comparison with conventional unit trust funds. Managerial Finance, 33(2), 142-153. http://doi.org/10.1108/03074350710715854

Aduda, J. M., \& Onsongo, E. N. (2012). The Determinants of Stock Market Development: The Case for the Nairobi Stock. International Journal of Humanities and Social Science, 2(9), 214-227

Bikhchandani, S., Hirshleifer, D. and Welch, I. (1992). A theory of fads, fashion, cus-tom, and cultural changes as informational cascades, journal of political economy 100(5)

Boortz, C., \& Kremer, S. (2013). Institutional herding in financial markets:New evidence through the Lens of a Simulated Model.

Brown, E.D, Nyeche, E.W (2016). The Imperative of Stock Market on Economic Growth in Nigeria: "The Endogenous Growth Model". Bus Eco J 7: 200. doi:10.4172/2151-6219.1000200

Cai, F., Han, S., \& Li, D. (2012). Institutional Herding in the Corporate Bond Market, (1071).

Chiang, T. C., \& Zheng, D. (2010). An Empirical Analysis of Herd Behavior in Global Stock Markets. Journal of Banking \& Finance, 34(8).

CMA. (2007). Investor Education (Vol. 2). http://doi.org/10.1007/s13398-014-0173-7.2

CMA. (2011). Proposed Intervention Measures Targeted at Boosting the Development of Islamic Capital Markets in Kenya, (December).

CMA. (2017). The CMA Quarterly Capital Markets Statistical Bulletin (Q1).

Graham, B. (1974). The Intelligent Investor, New York: Harper Business Essentials.

Gordon Newlove Asamoah (2008). The Impact of the Financial Sector Reforms on Savings, Investments and Growth of Gross Domestic Product (GDP) In Ghana. International Business \& Economics Research Journal, Volume 7, Number 10.

Kagunda, T. (2015). Asset Allocation by Fund Managers and The Financial Performance of Unit Trusts in Kenya. (Unpublished MBA Project). Nairobi University

Maina, R. W. (2013). the Effect of Capital Structure on the Financial Performance of Commercial Banks in Kenya, (November).

Maloba, M. H. (2012). The Existence Of Herd Behaviour : Evidence From The Nairobi Securities Exchange.

MINECOFIN. (2013). National Savings Mobilisation Strategy.

NEPAD Agency, UNECA (2013). Interim Report of the NEPAD/ECA Policy Study on Domestic Resource Mobilization for NEPAD Programmes

Nzoka, J. K. (2013). Factors Influencing Growth Strategies Of Fund Management Firms In Kenya, 2(9), $184-190$.

Onuora, R., Edith, U., \& Onyeanu, O. (2013). An Examination of the Unit Trust Scheme / Mutual Fund as a Veritable Vehicle of Investment in the Nigerian Stock Market ., 4(6), 176-184.

Rivera-Batiz, L. and Paul Romer. 1991. 'Economic integration and endogenous growth', Quarterly Journal of Economics 106, 531-566.

ROK. (2007). The Kenya Vision 2030. Government of The Republic of Kenya,. Retrieved from http://www.vision2030.go.ke/cms/vds/Popular_Version.pdf

Shefrin, H., \& Statman, M. (1985). The Disposition to Sell Winners Too Early and Ride Losers Too Long: Theory and Evidence, Journal of Finance, 40, 777-790.

Shikuku R. M. (2012), The Effects of Behavioural factors on investment decision Making by Unit Trust Companies in Kenya.(Unpublished MBA project). University of Nairobi

Smith, B. D. (1997). Financial markets in development, and the development of financial

Tabachnick, B. G., \& Fidell, L. S.(2001). Using multivariate statistics ( $4^{\text {th }}$ edn). New York: HarperCollins.

UNODC (2011). Estimating Illicit financial flows resulting from drug trafficking and other transnational organized crimes. Research Report markets, 21, 145-181.

Wamburu, K. K. \& Wainaina,G. (2014). Determinants of Stock Market Development in Kenya: An Error Correction Model Approach. European Journal of Business Management, 1 (11), 230-244.

Young, Alwyn. 1993. 'Invention and bounded learning by doing', Journal of Political Economy 101(3), 443-472. 